\title{
Ecologic ceramic substrates for CIGS solar cells
}

\author{
D. Fraga $^{*, 1}$, T. Stoyanova Lyubenova ${ }^{1}$, R. Martí ${ }^{1}$, I. Calvet ${ }^{1}$, E. Barrachina ${ }^{1}$ and J.B. \\ Carda $^{1}$ \\ ${ }^{1}$ Departamento de Química Inorgánica y Orgánica, Universitat Jaume I, Av. de Vicent \\ Sos Baynat s/n, 12071, Castellón (Spain)
}

*Corresponding autor: Tel.: +34964728234; Fax: +34964729016

E-mail adress: fraga@uji.es

\begin{abstract}
In this work the use of porcelain stoneware tiles as alternative substrates for CIGS thin film solar cells for the development of specific applications as those related to building integration (BIPV, BAPV) are reported. Two types of porcelain stoneware have been compared: the conventional tile (STD) and the ecological tile (ECO). The ECO ceramic paste formulation has been designed adding industrial wastes (recycled glass, sludges and chamote). Chemical, technological and functional properties of the paste have been performed. The CIGS absorber has been synthesized by an easy and low-cost way of preparation using co-precipitation method. The solar cell device has been completed and fully characterized.
\end{abstract}

The achieved results indicate better performances for ECO paste compared to the STD, stated in improved mechanical resistance, thickness and morphology. It is demonstrated 
that both tiles are suitable for solar cell applications, but ECO substrate developed higher energy conversion efficiency of $1.3 \%$.

Keywords: CIGS solar cell; ceramic tile; substrate; recycling 


\section{Introduction}

A thin film technology is an attractive option for substitution of the classical silicon crystalline solar cells. The films stand out for their flexibility to achieve large area modules, been able to adapt to uneven surfaces and to reduce materials and production costs [1]. $\mathrm{Cu}(\mathrm{In}, \mathrm{Ga}) \mathrm{Se}_{2}(\mathrm{CIGS})$ is an industrial leading technology, specially suitable for BIPV (Building-integrated photovoltaics) and BAPV (Building Attached Photovoltaics) applications [2-4]. This technology permits easy installation of the photovoltaic modules, bringing not only financial benefits from solar power generation, but also increasing the social values by making the buildings go green by simple retrofitting.

Recently, encouraging results have been obtained for CIGS based solar cells applied on soda-lime glasses and light-weight polymers [5, 6]. Record efficiencies of beyond 21.7 $\%$ at laboratory scale (small area), $15.9 \%$ for large-area and $12-13 \%$ for commercialized modules have been achieved [7-10]. The CIGS solar cells have also been settled on stainless steel [11-13] and aluminium sheets [14]. In Table 1 a brief review of the best performance solar cells on different substrates are summarized.

Table 1. Summary of the best performance solar cells on different substrates.

\begin{tabular}{cccccc}
\hline Substrate & $\begin{array}{c}\text { Absorber } \\
\text { material }\end{array}$ & $\begin{array}{c}\text { Deposition } \\
\text { method }\end{array}$ & Cell $\boldsymbol{\eta}(\%)$ & Institute & Reference \\
\hline Glass & CIGS & Co-evaporation & 21.7 & ZSW & {$[15]$} \\
Glass & CIGS & Electrodeposition & 17.3 & Nexcis & {$[16]$} \\
Polyimide & CIGS & Co-evaporation & 20.4 & EMPA & {$[17]$} \\
Stainless & CIGS & Electrodeposition & 15.4 & Solopower & {$[18]$} \\
Steel & \multirow{2}{*}{ CIGS } & Printing (ink) & 17.1 & Nanosolar & {$[19]$} \\
\hline
\end{tabular}


Conception of new architectural elements with added PV functionalities creates a strong interest in the analysis of the extension of these technologies to these new families of substrates. In this work, an extension of the CIGS based technologies to ceramic substrates is proposed, demonstrating its potential for the manufacture of low cost, and eco-friendly devices suitable for development of light solar modules that can be transferred from laboratory to pilot scale and then finally to production. Some initial steps have been reported for $\mathrm{CZTS}\left(\mathrm{Cu}_{2} \mathrm{ZnSn}(\mathrm{S}, \mathrm{Se})_{4}\right)$ compounds [20, 21].

The strong interest to design diverse photovoltaic (PV) architectural elements implies the need of technologies and compatible processes such as alternative to glasses substrates [20]. An advantage of the ceramic substrate is the possibility to operate at higher temperatures than the soda-lime glasses and the polymers. This is due to its higher thermal, chemical and mechanical stability, and low porosity [22]. Metals also present similar criteria, although their thermal expansion coefficient is higher than glasses and ceramics and, in addition, a barrier layer is usually required to release impurities that can diffuse into the absorber coating [23, 24]. The barrier layer used for devices is typically deposited by direct current (dc) sputtering or evaporation. However, in the case of the ceramic substrates the glaze works as a barrier layer, so there is no need to apply an extra layer. Besides, the ceramic manufacturing process allows the utilisation of inorganic residues as raw materials, becoming an environmental friendly industrial process [25-28].

The ceramic substrate for CIGS solar cells requires adequate adjustment. Thus, an introduction of extra layer based on enamel is needed. The enamel acts as an intermediate barrier between Mo back contact coating and the substrate providing chemical stability and roughness reduction, simulating glass surface with no porosity 
[29]. In addition, the enamel also prevents diffusions from the support to the Mo and the absorber CIGS layer and acts as $\mathrm{Na}$ and $\mathrm{K}$ source. It is demonstrated that small $\mathrm{Na}$ and K diffusion favours the CIGS crystallization process [30, 31].

On the other hand, the use of ecological products becomes of a vast importance in the ceramic industry nowadays in order to optimize the consumption of natural resources and to recycle by-products. The growing attention to the environmental safeguard is a result of a big environmental impact of the residuals and of increasing industrial costs. In order to improve the ceramic production benefits, research and development investments are strongly recommended for the industry subsistence, making the manufacturing of new environmentally friendly ceramic tiles an attractive opportunity $[32,33]$.

A porcelain stoneware paste is formed of clay, feldspar and quartz and is made by a spray-drying process [34-38]. Nowadays, the ceramic paste composition requires the use of kaolinitic clays and Na-K feldspar in order to achieve an adequate dimensional stability. The coefficient of thermal expansion (CTE) of the ceramic substrate is in the range of the CTE of CIGS [9]. The main criteria for the selection of a certain ceramic substrate are well-matched CTE $\left(7 \cdot 10^{-6} \mathrm{~K}^{-1}\right)$, excellent thermal $\left(\mathrm{T}>700{ }^{\circ} \mathrm{C}\right)$ and chemical resistivity, suitability for industrial deposition, and costs. The waste glass and sludge can form a vitreous microstructure during sintering of porcelain stoneware. Some papers consider that the introduction of waste glass in porcelain stoneware bodies can reduce the sintering temperature $[32,33,39]$.

Recycled glass can be obtained from several sources such as flat glass, glass bottle, lamps, television screens, etc. Moreover, its amorphous nature and composition (mainly silicon oxide $\left(\mathrm{SiO}_{2}\right)$, calcium oxide $(\mathrm{CaO})$ and sodium oxide $\left.\left(\mathrm{Na}_{2} \mathrm{O}\right)\right)$ make it an 
excellent candidate for application in the ceramic industry as flux agents in the formulation of ceramic glazes and engobes. In this sense, the recycled glass has to present an homogeneous chemical composition and to be available in large quantities [33].

In this paper, the development of new CIGS solar cell on different ceramic substrates is reported: a) standard porcelain stoneware tile (STD) and b) porcelain stoneware tile with waste (ECO). The wastes come from the ceramic industry, such as: chamote from fired porcelain, raw biscuit, sludge and cleaning water, as well as waste from other sectors such as the recycling glass. Therefore, it a solar cell based on CIGS technology that offers new possibilities for building integration photovoltaic (BIPV) can be obtained [40]. In addition, easy and low-cost ways of preparation using co-precipitation route for CIGS absorber is also described [41]. The developed powders were deposited on the substrate covering the back contacts (Mo contact layer) by doctor blade technique. On Figure 1 schematic design of the photovoltaic ceramic tile is shown.

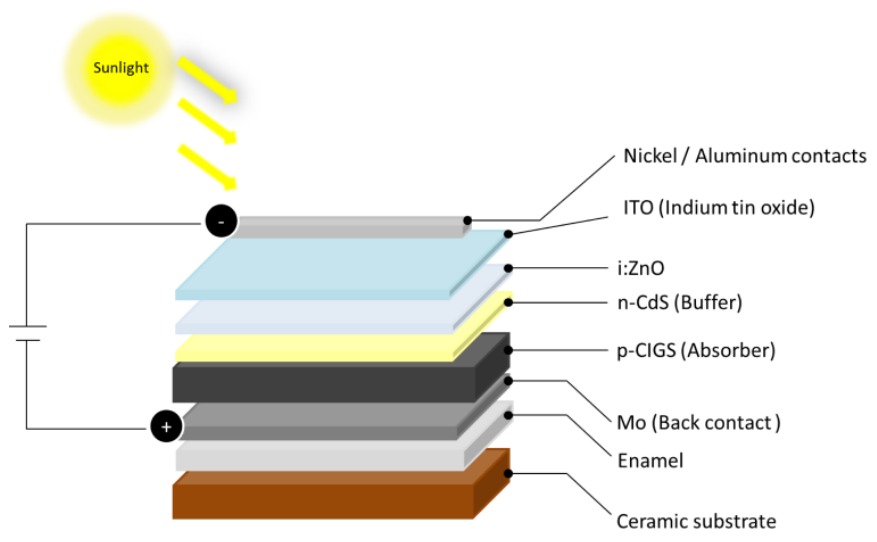

Figure 1. Schematic layout of a $\mathrm{Cu}(\mathrm{InGa}) \mathrm{Se}_{2}$-based photovoltaic ceramic tile. 


\section{Experimental details}

\subsection{Conventional ceramic body}

Porcelain stoneware tiles were made by traditional industrial ceramic method of preparation. The green bodies were prepared by pressing and further sintering in a conventional roller kiln.

\subsection{Eco-ceramic body}

The followed methodology in this section consisted of the formulation of a stoneware porcelain composition, using kaolinitic clay (40-50\%wt.), feldspar (30-35\%wt.), feldspathic sand (5-10\% wt.) and also waste materials (15-20\%wt.). The waste materials contain glass waste (sodium-calcium nature), chamote from fired porcelain of stoneware and raw biscuit $[32,33]$.

\subsection{Enamel}

The conventional and the eco-ceramic bodies were covered by industrial enamel in order to offer chemical stability and roughness reduction, simulating glass surface with no porosity [29]

\subsection{CIGS synthesis and deposition}


$\mathrm{CuIn}{ }_{0.7} \mathrm{Ga}_{0.3} \mathrm{Se}_{2}$ solid solution was synthesized using co-precipitation route keeping atomic ratio of $\mathrm{Cu} /(\mathrm{In}+\mathrm{Ga})=0.92$ and $\mathrm{Ga} /(\mathrm{In}+\mathrm{Ga})=0.3[40,42,43]$. The resulting CIGS powder was further mixed with triethanolamine (TEA, 99\%, Riedel-de Haën) and ethanol $\left(\mathrm{C}_{2} \mathrm{H}_{5} \mathrm{OH}, 99.9 \%\right.$, Sharlau $)$ to form slurry that was deposited on ceramic substrate by manual doctor blade method $[29,41]$. The slurry viscosity and the blade gap mainly govern the thickness precision. The obtained layer was pre-heated on a hot plate at $400^{\circ} \mathrm{C}$ for $2 \mathrm{~min}$ to partially remove the solvent and to encourage further precursor decomposition. Finally, the CIGS films were selenised using elemental Se under an Ar atmosphere in a tubular furnace. The applied thermal cycle corresponds to heating velocity rate of $20^{\circ} \mathrm{C} / \mathrm{min}$ up to maximum temperature of $525^{\circ} \mathrm{C}$.

The solar cells were completed depositing CdS $(60 \mathrm{~nm})$ by chemical bath deposition (CBD) above the absorber layers. The i-ZnO layer with $50 \mathrm{~nm}$ thickness was deposited by the DC-pulsed sputtering deposition using $\mathrm{ZnO}$ target and $\mathrm{Ar} / \mathrm{O}_{2}$ mixture as process gas. The cells were completed with the deposition of a conductive indium tin oxide (ITO). For the optoelectronic characterization $3 \times 3 \mathrm{~mm}^{2}$ cells were scribed using a micro diamond scriber MR200 OEG.

\subsection{Characterization techniques}

Porcelain stoneware composition has been studied by X-Ray Fluorescence (XRF), using a sequential spectrometer X-ray scattering wavelengths S4 Pioneer by Bruker with a Rh X-ray tube of $4 \mathrm{~kW}$. The sintering parameters, referred to the linear shrinkage variation $(\%)$ and the water absorption (\%), were used to observe the paste behaviour versus firing temperature. The glaze surfaces were studied by Atomic Force Microscope 
(AFM) with a JSPM-5200 JEOL Scanning Probe Microscope operating in contact approach.

The flexural tensile strength of the fired tiles obtained has been analysed by means of equipment called crometer model Crometro CR5-1000 Gabbrielli, based on pneumo hydraulic operation and a maximum applied pressing force of $1000 \mathrm{~kg}$.

The crystal structure of the CIGS powders and films was monitored by X-ray diffraction (XRD) using a D4 Endeavor, Bruker-AXS equipped with a $\mathrm{Cu} \mathrm{K} \alpha$ radiation source. Data was collected by step-scanning from $10^{\circ}$ to $80^{\circ}$ with step size of $0.05^{\circ} 2 \theta$ and $1 \mathrm{~s}$ counting time per step. The particle sizes were quantitatively evaluated from the XRD data using the Debye-Scherrer equation [44],

$$
D=\frac{k \lambda}{\beta \cos \theta}
$$

where $\mathrm{k}$ is Scherrer constant $(0.89), \lambda$ the $X$-ray wavelength $(0.15405 \mathrm{~nm}), \beta$ the peak width of half-maximum, and $\theta$ is the Bragg diffraction angle.

Scanning Electron Microscopy (SEM) model JEOL 7001F attached with an energy dispersive X-ray analysis (EDX) was employed to study the morphology and elemental composition of the films. The layer thickness was valued from cross-section. micrographs. Adhesion between back contact layers and support was measured using laboratory test method by applying and removing tape and scratching of the surface. These test methods are used to establish whether the adhesion of a coating on a substrate is suitable.

The optical properties and band gap energy of the CIGS layer was conducted by UVVis-NIR spectroscopy in the wavelength range 200-1200 $\mathrm{nm}$ (step size $1 \mathrm{~nm}$ ) using a 
Cary 500 Scan Varian spectrophotometer. The absorption spectra were obtained applying $\mathrm{BaSO}_{4}$ integrating sphere as a white reference material. The optical band gap (Eg) of CIGS semiconductor, was calculated following the Tauc's relation $\alpha=\mathrm{A}_{\alpha} / \mathrm{hv}$ $[\mathrm{hv}-\mathrm{Eg})]^{1 / 2}$ where, $\mathrm{A}_{\alpha}$ is a constant that depends on the transition nature, the effective mass and the reflective index and $\mathrm{E}=\mathrm{h} v$ is the incident photon energy $[45,46]$.

The solar cells were optoelectronically characterized through I-V curves and External Quantum Efficiency (EQE) measurements. A Sun 3000 class AAA solar simulator from Abet Technology (uniform illumination area of $15 \times 15 \mathrm{~cm}^{2}$ ) was used. Measurements were carried out after the calibration of the system with a reference Si solar cell under AM 1.5 illumination and fixing the temperature of the samples to $298 \mathrm{~K}$. The EQE of the cells was measured with a Bentham PVE300 system in the 300-1600 nm wavelength range, and was calibrated using Si and Ge photodiodes.

\section{Results and Discussion}

\subsection{Ceramic substrates}

Chemical analysis of the STD and the ECO ceramic body were determined by X-ray fluorescence (XRF). Results of the chemical analysis are observed in Table 2. The chemical composition of both, STD and ECO pastes, are very similar. An increment of about $10 \%$ of $\mathrm{Na}_{2} \mathrm{O}$ and $20 \%$ of $\mathrm{CaO}$ content is detected in the $\mathrm{ECO}$ paste, due to the addition of $5 \%$ of recycled glass with alkaline nature (soda-lime glass). The glass acts as a flux agent in the paste composition improving it fluidity [33]. 
Table 2. Chemical analysis performed by FRX of ecologic ceramic paste (ECO) and conventional ceramic paste (STD).

\begin{tabular}{cccccccccccc}
\hline & $\mathrm{Na}_{2} \mathrm{O}$ & $\mathrm{MgO}$ & $\mathrm{Al}_{2} \mathrm{O}_{3}$ & $\mathrm{SiO}_{2}$ & $\mathbf{P}_{2} \mathrm{O}_{\mathbf{5}}$ & $\mathrm{K}_{2} \mathrm{O}$ & $\mathbf{C a O}$ & $\mathbf{T i O}_{2}$ & $\mathbf{F e}_{2} \mathrm{O}_{3}$ & LOI $^{*}$ & $\mathbf{S U M}^{*}$ \\
\hline STD & 4.33 & 0.48 & 19.15 & 68.78 & 0.10 & 1.32 & 0.68 & 0.67 & 0.65 & 3.84 & 100 \\
ECO & 4.83 & 0.50 & 19.00 & 68.45 & 0.09 & 1.33 & 0.88 & 0.68 & 0.69 & 3.55 & 100 \\
\hline
\end{tabular}

*LOI (Loss on ignition) - consists of heating a sample of the material at a specified temperature, allowing volatile substances to escape, until its mass ceases to change. *SUM (sum of all components)

A sintering process of both ceramic bodies is displayed in Figure 2, exhibiting similar behaviour: linear shrinkage (\% L.S.) about 7,68 \% and water absorption (\% W.A.) around $0,11 \%$ can be observed in the ECO samples, while the STD sample presents $7,73 \%$ (\% L.S.) and $0,67 \%(\%$ W.A. $)$ values corresponding at $1165^{\circ} \mathrm{C}$. It can be highlighted that the ECO paste maintains almost $0 \%$ of water absorption above $1165^{\circ} \mathrm{C}$, while STD hasn't reached yet the zero porosity at that temperature. This happens thanks to the flux (soda-lime glass) that promotes melting.

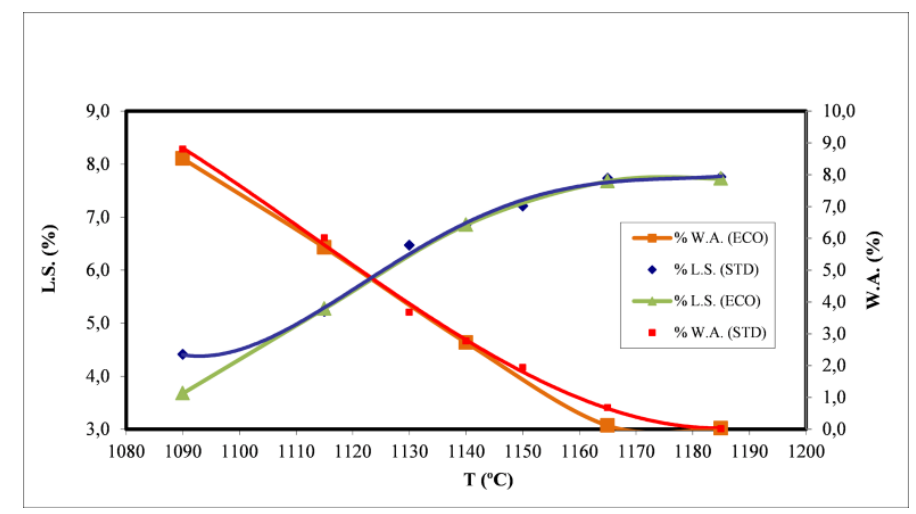

Figure 2. Linear shrinkage and water absorption obtained in the sintering process for STD and ECO ceramic pastes.

The flexural tensile strength of fired pieces is based on the 3-points method and has been measured at maximum sintering temperature $\left(1185^{\circ} \mathrm{C}\right)$. Thus, the result corresponding to the STD tile is around $57 \mathrm{~N} / \mathrm{mm}^{2}$, while the ECO sample exhibits a 
value near $60 \mathrm{~N} / \mathrm{mm}^{2}$, been both suitable data to be used as ceramic tile, according to the UNE-EN-ISO 10545-4. These results are favored by the higher mechanical strength of the ECO tile and permit to obtain porcelain stoneware tile with reduced thickness $(<$ $3 \mathrm{~mm})$.

\subsection{Enamel surface study}

Cross section of the porcelain stoneware tile is observed in Figure 3. It can be observed three different areas: enamel, engobe and porcelain stoneware body. The enamel shows a compact morphology with some cavities as a result of $\mathrm{CO}_{2}$ volatilization from the ceramic inner reactions. The engobe has a sponge microstructure with numerous pores with diverse dimensions and irregular distribution. The tile body evidences a solid microstructure with some holes and cracks. Differences in enamel microstructure are detected for both samples. The STD tile (Fig.3a) exhibits large and mostly opened surface holes $(>30 \mu \mathrm{m})$ in the volume, while the ECO tile have only a few small defects randomly dispersed in the bulk (Fig. 3b). These variations could affect the final device effectiveness as STD sample demonstrates worst behaviour than ECO tile.
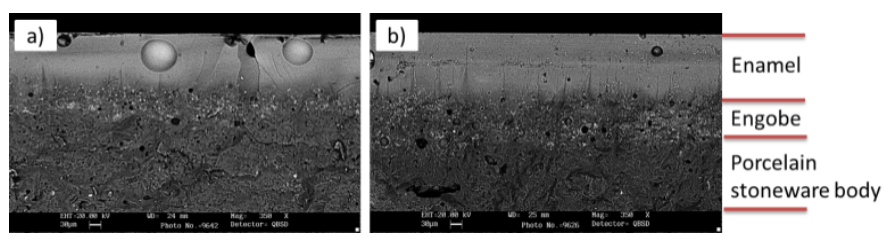

Figure 3. Cross section micrographs of the samples: a) STD and b) ECO porcelain stoneware tiles.

Figure 4 displays the AFM images of the enamel layer of the STD and the ECO ceramic substrates. Smooth surface can be observed in the both cases. The STD ceramic 
substrate shows clear absence of particles scattered. The difference between lowest and highest surface points (so called depth) in the studied area exceeds $50 \mathrm{~nm}$. The average roughness of the sample is $9.51 \mathrm{~nm}$. The ECO ceramic substrate displays smoother surface with depth below $17 \mathrm{~nm}$ and average roughness of $1.74 \mathrm{~nm}$. This fact suggests that ECO ceramic substrate is very similar to glasses, so could be suitable for uses as a substrate for CIGS-based photovoltaic device.

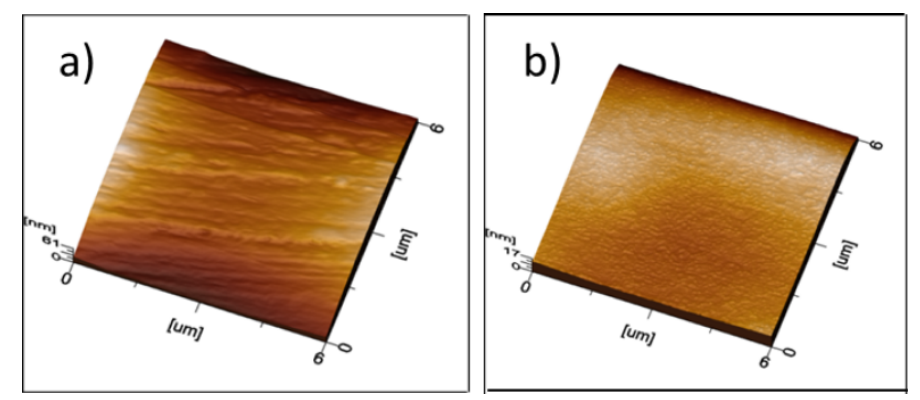

Figure 4. AFM images of a) STD ceramic tile and b) ECO ceramic tile.

\subsection{CIGS solar cell assembly film characterization}

The X-ray diffraction spectra of CIGS films treated at $525^{\circ} \mathrm{C}$ are exposed in Figure 5.

The main diffraction peaks of both samples could be assigned to $\mathrm{CuIn}_{0,7} \mathrm{Ga}_{0,3} \mathrm{Se}_{2}$ (CIGS) crystalline phase (JCPDS 35-1102). The highest Mo back contact reflection is observed at $40.6^{\circ} 2$ theta (110) (JCPDS 42-1120). A secondary pick was detected in sample (a) that could be assigned to $\mathrm{Cu}_{0.79} \mathrm{In}_{0.78} \mathrm{Se}_{1.8}$ phase (JCPDS 01-079-2208). The CIGS particle sizes were quantitatively evaluated from the XRD data (Fig. 5 using the DebyeScherrer equation (1)). From the d-spacing $(1,1,2),(2,2,0)$ and $(3,1,2)$ the crystallite dimensions were calculated. The particles measure spans: from $12 \mathrm{~nm}$ to $40 \mathrm{~nm}$ for sample (a) and from $30 \mathrm{~nm}$ to $50 \mathrm{~nm}$ for sample (b). 


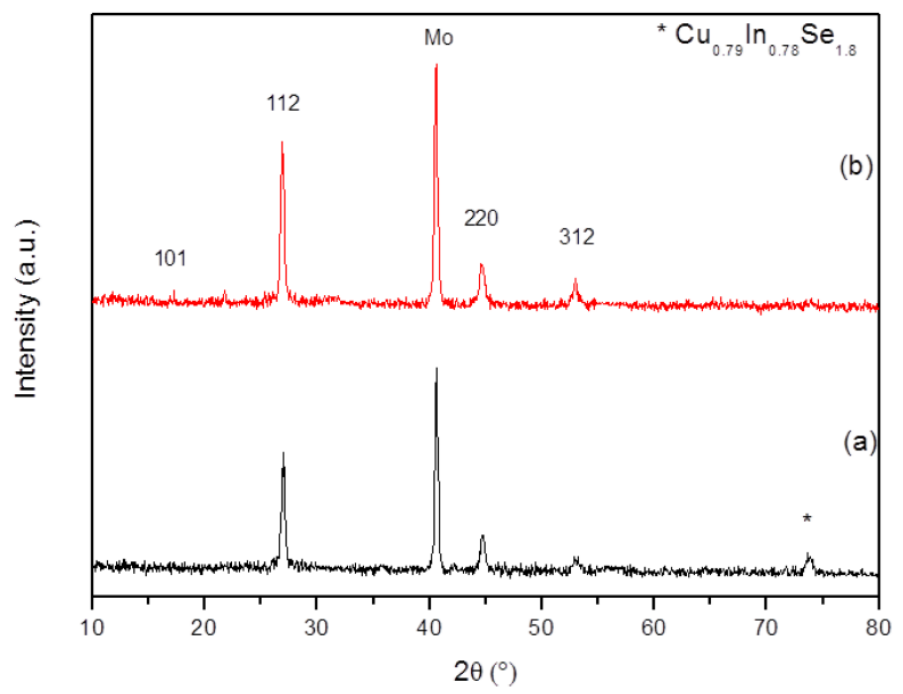

Figure 5. XRD data of the CIGS films: a) STD tile and b) ECO tile.
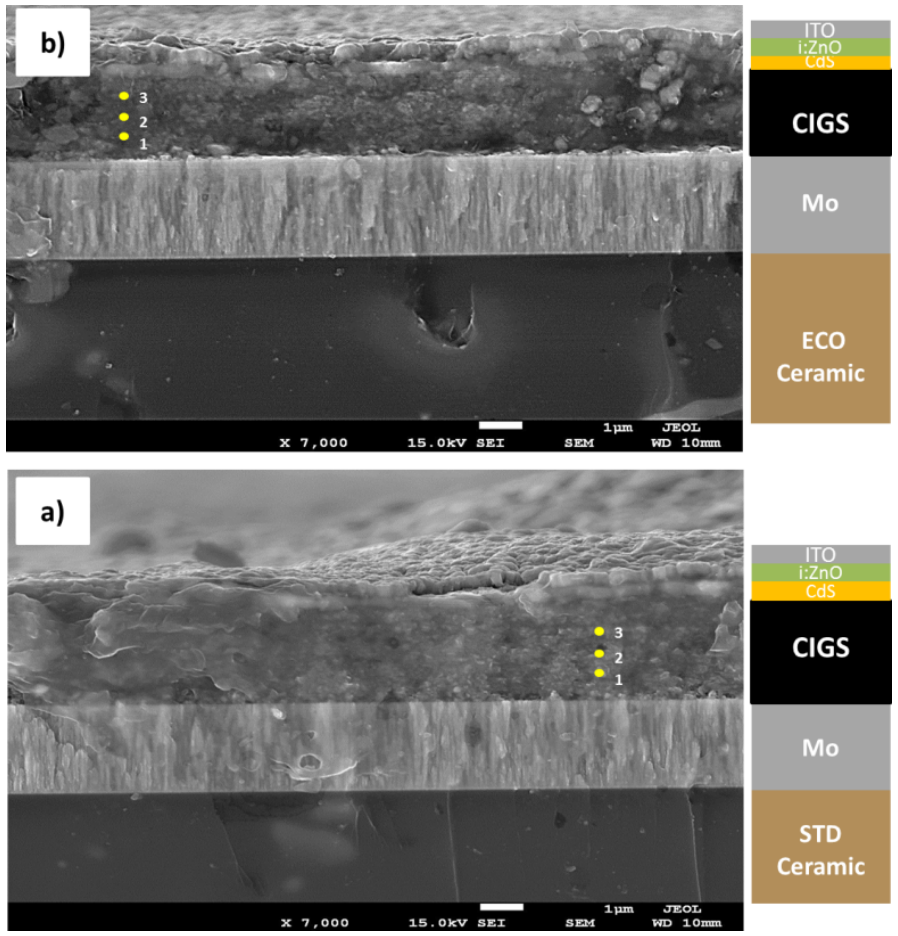

CIGS

Mo

STD

Ceramic

Figure 6. Cross section SEM images of CIGS device: a) STD ceramic and b) ECO ceramic substrates. 
Table 3. EDX analysis (atomic \%) and metal ratio of CIGS.

\begin{tabular}{cccccccc}
\hline \multirow{2}{*}{ Sample } & $\begin{array}{c}\text { Point of } \\
\text { analysis }\end{array}$ & $\begin{array}{c}\text { Cu } \\
\text { (at.\%) }\end{array}$ & $\begin{array}{c}\text { In } \\
\text { (at.\%) }\end{array}$ & $\begin{array}{c}\text { Ga } \\
\text { (at.\%) }\end{array}$ & $\begin{array}{c}\text { Se } \\
\text { (at.\%) }\end{array}$ & Cu/In+Ga & Ga/In+Ga \\
\hline \multirow{2}{*}{ STD } & 1 & 27.41 & 13.38 & 5.04 & 54.17 & 1.48 & 0.27 \\
& 2 & 28.04 & 12.25 & 6.11 & 53.60 & 1.52 & 0.33 \\
& 3 & 29.20 & 11.35 & 5.73 & 53.72 & 1.70 & 0.33 \\
\hline \multirow{2}{*}{ ECO } & 1 & 27.14 & 12.81 & 5.57 & 54.48 & 1.47 & 0.30 \\
& 2 & 28.48 & 13.04 & 5.97 & 52.51 & 1.49 & 0.31 \\
& 3 & 30.08 & 14.34 & 5.51 & 50.08 & 1.51 & 0.28 \\
\hline
\end{tabular}

Figure 6 shows a cross section of the CIGS layers after selenization. In both cases, dense layers well attached to the Mo are formed. Absence of holes and cracks is also evident. In case of the ECO tile, slightly bigger crystals are observed. This result fits with the XRD data discussed before. The lack of large grains could be due to the use of a solution based on amine compounds. It is demonstrated that these binders inhibit the crystal growth [47], an undesirable effect for the solar cell morphology. However, the amines were used to enhance the reduction process and further CIGS formation, an essential step in the proposed synthesis procedure. The total thickness of both CIGS layers after the thermal treatment is approximately $2 \mu \mathrm{m}$, which is enough for the PV devices.

The CIGS elemental composition (Table 3) was determined by energy-dispersive X-ray analysis (EDX). Dotted lines in Figure $6 \mathrm{a}$ and $6 \mathrm{~b}$ indicate the semi-quantitative analysis (atomic \%) of CIGS stoichiometry. The elemental concentration is indicated with dots along the depth in three different areas: bottom (1), middle (2) and top (3). The results from the Table 3 display Cu-rich CIGS absorber with very similar composition for both ceramic tiles. Only, a higher deviation from the stoichiometry is observed for the STD composition towards the surface area. 
The absorption $\alpha$ as a function of wavelength using UV-Vis-NIR to determine the band gap of the CIGS layer was measured (Fig. 7). The band gap Eg was calculated by plot of $(E \alpha)^{2}$ with photon energy (E); for all absorption layers as depicted in Figure 7. The STD sample shows a band gap of $1.26 \mathrm{eV}$, while the ECO sample corresponds to 1.24 $\mathrm{eV}$. The obtained values are close to those reported in the literature for $\mathrm{CuIn}{ }_{0.7} \mathrm{Ga}_{0.3} \mathrm{Se}_{2}$ $(1.24 \mathrm{eV})$ [48]. The ECO tile fits exactly with the calculated for this solid dissolution value.

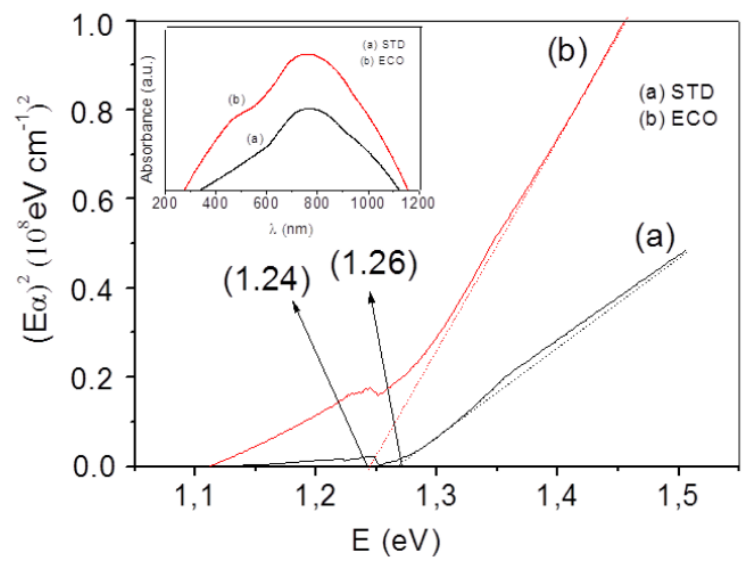

Figure 7. Plot of $(\mathrm{E} \alpha)^{2}$ with photon energy (hv) for band gap measured for CIGS absorption layer a) STD and b) ECO tiles. The inset view displays UV-VIS-NIR spectra of absorbance vs. wavelength for CIGS layer: a) STD and b) ECO ceramic sample. 


\subsection{Device Characterization}

The CIGS devices were optoelectronically characterized through I-V curves and external quantum efficiency (EQE) measurements under AM1.5 global spectrum (Fig. 8). The photovoltaic behaviour in ECO ceramic sample with an open-circuit voltage $\left(\mathrm{V}_{\mathrm{oc}}\right)=270 \mathrm{mV}$, short-circuit current density $\left(\mathrm{J}_{\mathrm{sc}}\right)=13.43 \mathrm{~mA} / \mathrm{cm}^{2}$, fill factor $(\mathrm{FF})=36$ $\%$, efficiency $(\eta)=1.3 \%$, and device area $=0.087 \mathrm{~cm}^{2}$ is similar to the STD sample, whose photovoltaic behaviour is characterized by an open-circuit voltage $\left(\mathrm{V}_{\mathrm{oc}}\right)=220$ $\mathrm{mV}$, a short-circuit current density $\left(\mathrm{J}_{\mathrm{sc}}\right)=10.28 \mathrm{~mA} / \mathrm{cm}^{2}$, fill factor $(\mathrm{FF})=32 \%$, efficiency $(\eta)=0.7 \%$, and device area $=0.087 \mathrm{~cm}^{2}$.

It can be observed that it is possible to prepare a photovoltaic device based on film layer technology, using glazed tiles, a conventional tile or an ecological one, the last containing industrial waste as part of raw materials for the ceramic paste formulation.

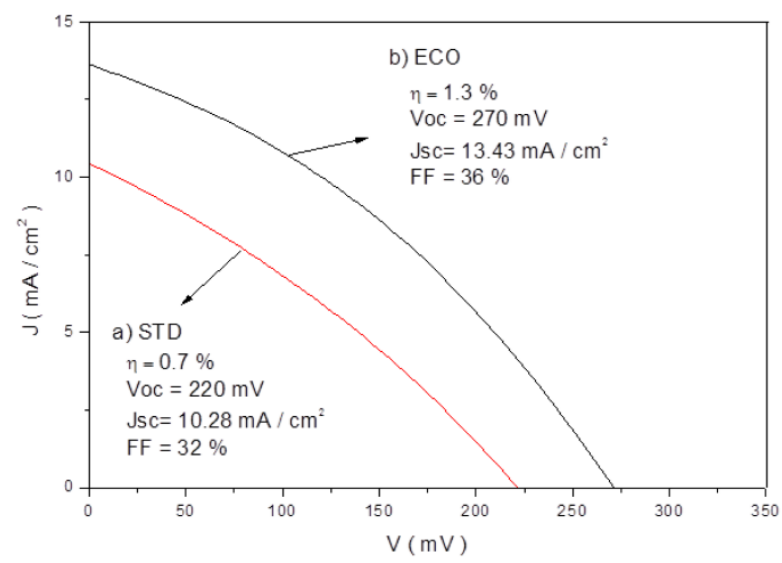

Figure 8. I-V curves and External Quantum Efficiency (EQE) measurements. 


\section{Conclusion}

Porcelain stoneware tiles as alternative substrates for CIGS thin film solar cells have been developed. The CIGS absorber has been synthesized and the solar cell device has been completed and characterized.

The designed ECO substrate, including industrial wastes in it paste formulation, achieved better results in terms of lower porosity and water absorption, mechanical resistance, lower body thickness and improved morphology. These characteristics render it as a proper substrate for photovoltaic applications developing device with 1.24 $\mathrm{eV}$ of band gap and efficiency of $1.3 \%$. The standard ceramic tile (STD) is an alternative possibility for substrate, but exhibit inferior technological performances and assembly effectiveness of $0.7 \%$.

The co-precipitation of selenite precursors results in obtaining of $\mathrm{Cu}$-rich CIGS solid solution. Adequate compatibility between CIGS and ceramic substrate was obtained keeping layer thickness and chemical composition suitable for PV applications.

In summary, an ecologic porcelain stoneware tile has been developed, demonstrating to be suitable as a substrate for CIGS thin film solar cell. The device allows both, functionality and energy saving during the manufacturing process. 


\section{Acknowledgements}

The authors would like to acknowledge the financial support of the Spanish Ministry of Economy and Competitiveness under the program RETOS-COLABORACION (RTC2014-2294-3). We also appreciate the characterization assistance of Central Service of Scientific Instrumentation (SCIC) at the University Jaume I and Torrecid Group S.A. 


\section{REFERENCES}

[1] K.L. Chopra, P.D. Paulson, V. Dutta, Thin-film solar cells: an overview, Prog. Photovoltaics, 12 (2004) 69-92.

[2] B. Petter Jelle, C. Breivik, H. Drolsum Røkenes, Building integrated photovoltaic products: A state-of-the-art review and future research opportunities, Sol. Energy Mater. Sol. Cells, 100 (2012) 69-96.

[3] B.P. Jelle, C. Breivik, State-of-the-art Building Integrated Photovoltaics, Energy Procedia, 20 (2012) 68-77.

[4] B.P. Jelle, C. Breivik, The Path to the Building Integrated Photovoltaics of Tomorrow, Energy Procedia, 20 (2012) 78-87.

[5] K. Zhang, C.-1. Yang, L. Yin, Z. Liu, Q.-m. Song, H.-1. Luo, Z.-y. Xiong, M.-m. Xu, X.-d. Xiao, Fabricating highly efficient $\mathrm{Cu}(\mathrm{In}, \mathrm{Ga}) \mathrm{Se}_{2}$ solar cells at low glass-substrate temperature by active gallium grading control, Sol. Energy Mater. Sol. Cells, 120 (2014) 253-258.

[6] P. Reinhard, F. Pianezzi, L. Kranz, S. Nishiwaki, A. Chirilă, S. Buecheler, A.N. Tiwari, Flexible $\mathrm{Cu}(\mathrm{In}, \mathrm{Ga}) \mathrm{Se}_{2}$ solar cells with reduced absorber thickness, Prog. Photovoltaics, 23 (2015) 281-289.

[7] P. Reinhard, S. Buecheler, A.N. Tiwari, Technological status of $\mathrm{Cu}(\mathrm{In}, \mathrm{Ga})(\mathrm{Se}, \mathrm{S})_{2^{-}}$ based photovoltaics, Sol. Energy Mater. Sol. Cells, 119 (2013) 287-290.

[8] S. Furue, S. Ishizuka, A. Yamada, M. Iioka, H. Higuchi, H. Shibata, S. Niki, $\mathrm{Cu}(\mathrm{In}, \mathrm{Ga}) \mathrm{Se}_{2}$ solar cells and mini-modules fabricated on thin soda-lime glass substrates, Sol. Energy Mater. Sol. Cells, 119 (2013) 163-168.

[9] F. Kessler, D. Rudmann, Technological aspects of flexible CIGS solar cells and modules, Sol. Energy, 77 (2004) 685-695. 
[10] M. Powalla, W. Witte, P. Jackson, S. Paetel, E. Lotter, R. Wuerz, F. Kessler, C. Tschamber, W. Hempel, D. Hariskos, R. Menner, A. Bauer, S. Spiering, E. Ahlswede, T.M. Friedlmeier, D. Blazquez-Sanchez, I. Klugius, W. Wischmann, CIGS Cells and Modules With High Efficiency on glass and flexible substrates, IEEE J. Photovolt, 4 (2014) 440-446.

[11] F. Pianezzi, A. Chirilă, P. Blösch, S. Seyrling, S. Buecheler, L. Kranz, C. Fella, A.N. Tiwari, Electronic properties of $\mathrm{Cu}(\mathrm{In}, \mathrm{Ga}) \mathrm{Se}_{2}$ solar cells on stainless steel foils without diffusion barrier, Prog. Photovoltaics, 20 (2012) 253-259.

[12] K. Moriwaki, M. Nomoto, S. Yuuya, N. Murakami, T. Ohgoh, K. Yamane, S. Ishizuka, S. Niki, Monolithically integrated flexible $\mathrm{Cu}(\mathrm{In}, \mathrm{Ga}) \mathrm{Se}_{2}$ solar cells and submodules using newly developed structure metal foil substrate with a dielectric layer, Sol. Energy Mater. Sol. Cells, 112 (2013) 106-111.

[13] R. Wuerz, A. Eicke, F. Kessler, S. Paetel, S. Efimenko, C. Schlegel, CIGS thinfilm solar cells and modules on enamelled steel substrates, Sol. Energy Mater. Sol. Cells, 100 (2012) 132-137.

[14] D. Brémaud, D. Rudmann, M. Kaelin, K. Ernits, G. Bilger, M. Döbeli, H. Zogg, A.N. Tiwari, Flexible $\mathrm{Cu}(\mathrm{In}, \mathrm{Ga}) \mathrm{Se}_{2}$ on $\mathrm{Al}$ foils and the effects of $\mathrm{Al}$ during chemical bath deposition, Thin Solid Films, 515 (2007) 5857-5861.

[15] P. Jackson, D. Hariskos, R. Wuerz, O. Kiowski, A. Bauer, T.M. Friedlmeier, M. Powalla, Properties of $\mathrm{Cu}(\mathrm{In}, \mathrm{Ga}) \mathrm{Se}_{2}$ solar cells with new record efficiencies up to 21.7\%, Phys. status solidi - Rapid Res. Lett., 9 (2015) 28-31.

[16] C. Insignares-Cuello, F. Oliva, M. Neuschitzer, X. Fontané, C. Broussillou, T. Goislard de Monsabert, E. Saucedo, C.M. Ruiz, A. Pérez-Rodríguez, V. IzquierdoRoca, Advanced characterization of electrodeposition-based high efficiency solar cells: Non-destructive Raman scattering quantitative assessment of the anion chemical 
composition in $\mathrm{Cu}(\mathrm{In}, \mathrm{Ga})(\mathrm{S}, \mathrm{Se})_{2}$ absorbers, Sol. Energy Mater. Sol. Cells, 143 (2015) 212-217.

[17] K.E. Martin A. Green, Y. Hishikawa, W. Warta and Ewan D. Dunlop, Solar cell efficiency tables (version 42), Prog. Photovoltaics, 21 (2013) 827-837.

[18] S. Aksu, S. Pethe, A. Kleiman-Shwarsctein, S. Kundu, M. Pinarbasi, Recent Advances in Electroplating Based CIGS Solar Cell Fabrication., Proc. 38th IEEE Photovoltaics Specialists Conference, (2012) 3092-3097.

[19] G. Brown, P. Stone, J. Woodruff, B. Cardozo, D. Jackrel, Device Characteristics of a $17.1 \%$ Efficient Solar Cell Deposited by a non-vacuum printing method on flexible foil, Proc. 38th IEEE Photovoltaics Specialists Conference, (2012) 3280-3233.

[20] I. Calvet, E. Barrachina, R. Martí, D. Fraga, T. Stoyanova Lyubenova, J.B. Carda, Development of photovoltaic ceramic tile based on CZTSSe absorber, Mater. Lett, 161 (2015) 636-639.

[21] I. Calvet, E. Barrachina, R. Martí, D. Fraga, T.S. Lyubenova, J.B. Carda, Synthesis, deposition and crystal growth of CZTS nanoparticles onto ceramic tiles, Bol. Soc. Esp. Ceram. V., 54 (2015) 175-180.

[22] M.P. Seabra, L. Grave, C. Oliveira, A. Alves, A. Correia, J. Labrincha, Porcelain stoneware tiles with antimicrobial action, Ceram. Int, 40 (2014) 6063-6070.

[23] W.S. Liu, H. Hu, N. Pu, S. Liang, Developing flexible CIGS solar cells on stainless steel substrates by using Ti/TiN composite structures as the diffusion barrier layer, $\mathrm{J}$. Alloy. Compd. 631 (2015) 146-152.

[24] D. Askeland, W Wright, The Science and Engineering of Materials, Boston: Global Engineering: Tomothy L. Anderson. 2015.

[25] L. Zhang, Production of bricks from waste materials - A review, Constr. Build. Mater., 47 (2013) 643-655. 
[26] V.S. Nandi, F. Raupp-Pereira, O.R.K. Montedo, A.P.N. Oliveira, The use of ceramic sludge and recycled glass to obtain engobes for manufacturing ceramic tiles, J. Clean Prod. 86 (2015) 461-470.

[27] S.N. Monteiro, C.M.F. Vieira, On the production of fired clay bricks from waste materials: A critical update, Constr. Build. Mater. 68 (2014) 599-610.

[28] S.S. H. Celik, and Ö. Öney, The use of tincal calcination plant waste as an additive in ceramic wall tile production, J. Ceram. Process. Res. 15 (2014) 508-513.

[29] D. Fraga, T.S. Lyubenova, A. Rey, I. Calvet, R. Martí, J.B. Carda, Ceramic Enamels as New Back Contacts for $\mathrm{Cu}(\mathrm{In}, \mathrm{Ga}) \mathrm{Se}_{2}$-Based Photovoltaic Tile, Int. J. Appl. Ceram. Tec. 12 (2015) 728-737.

[30] M. Lee, S. Lee, S. Jung, S. Ahn, J. Cho, J. Park, Y. Eh, J. Gwak, K. Shin, K. Yoon, Y. Cho, J. Yun, Highly efficient flexible $\mathrm{CuIn}_{0.7} \mathrm{Ga}_{0.3} \mathrm{Se}_{2}$ solar cells with a thick $\mathrm{Na} / \mathrm{Mo}$ layer deposited directly on stainless steel, Appl. Surf. Sci. 346 (2015) 562-566.

[31] A. Laemmle, R. Wuerz, M. Powalla, Investigation of the effect of potassium on $\mathrm{Cu}(\mathrm{In}, \mathrm{Ga}) \mathrm{Se}_{2}$ layers and solar cells, Thin Solid Films, 582 (2015) 27-30.

[32] D. Fraga, A. Gyozova, S. Kozhukharov, S. Allepuz, C. Lázaro, V.R. Trilles, Juan B. Carda, Development of New Ecological Ceramic Tiles by Recycling of Waste Glass and Ceramic Materials, Anual conference University of Ruse “Angel Kunchev”, Proc. Chemical Tecnology, 50 (9.1) (2011) 8-13.

[33] C. Lázaro, V. Ramón Triles, F. Gómez, D. Fraga, J.B. Carda, Incorporación de residuos derivados de la fabricación cerámica y del vidrio reciclado en el proceso cerámico integral, Bol. Soc. Esp. Ceram. V., 51 (2012) 139-144.

[34] M. Dondi, M. Raimondo, C. Zanelli, Clays and bodies for ceramic tiles: Reappraisal and technological classification, Appl. Clay Sci., 96 (2014) 91-109. 
[35] J. M. Pérez, M. Romero, Microstructure and technological properties of porcelain stoneware tiles moulded at different pressures and thicknesses, Ceram. Int. 40 (2014) $1365-1377$.

[36] E. Rambaldi, L. Esposito, A. Tucci, G. Timellini, Recycling of polishing porcelain stoneware residues in ceramic tiles, J. Eur. Ceram. Soc. 27 (2007) 3509-3515. [37] E. Barrachina, J. Llop, M. Notari, D. Fraga, R. Martí, I. Calvet, A. Rey, T. Stoyanova Lyubenova, S. Kozhukharov, V. Kozhukharov, J. Carda, Study of different deflocculation mechanisms for porcelain ceramic paste, Annual conference University of Ruse "Angel Kunchev", Proc. Chemical Tecnology, 53 (2014) 14-17. [38] E. Barrachina, J. Llop, M. Notari, D. Fraga, R. Martí, I. Calvet, A. Rey, T. Lyubenova, S. Kozhukharov, V. Kozhukharov,J.B. Carda, Rheological effect of different deflocculation mechanisms on a porcelain ceramic composition, J. Chem. Technol. Metall., 50 (2015) 493-502.

[39] A. Tucci, Use of soda-lime scrap-glass as a fluxing agent in a porcelain stoneware tile mix, J. Eur. Ceram. Soc., 24 (2004) 83-92. [40] L. Oliveira,T. Lyubenova, R. Martí, D. Fraga, A. Rey, V. Kozhukharov, J. Carda, In-situ sol-gel synthesis and thin film deposition of $\mathrm{Cu}(\mathrm{In}, \mathrm{Ga})(\mathrm{S}, \mathrm{Se})_{2}$ solar cells, J. Chem. Technol. Metall., 48 (2013) 559-566.

[41] R. Martí, L. Oliveira, T. S. Lyubenova, T. Todorov, E. Chassaing, D. Lincot, J.B. Carda, Preparation of $\mathrm{Cu}(\mathrm{In}, \mathrm{Ga}) \mathrm{Se}_{2}$ photovoltaic absorbers by an aqueous metal selenite co-precipitation route, J. Alloy. Compd., 650 (2015) 907911.

[42] M. A. Contreras, M. J. Romero, R. Noufi, Characterization of $\mathrm{Cu}(\mathrm{In}, \mathrm{Ga}) \mathrm{Se}_{2}$ materials used in record performance solar cells, Thin Solid Films, 511-512 (2006) 5154. 
[43] S. Jung, S. Ahn, J.H. Yun, J. Gwak, D. Kim, K. Yoon, Effects of Ga contents on properties of CIGS thin films and solar cells fabricated by co-evaporation technique, Curr. Appl. Phys., 10 (2010) 990-996.

[44] A.L. Patterson, The Scherrer Formula for X-Ray Particle Size Determination, Physical Review, 56, (1939) 978-982.

[45] S. Kang, R. Sharma, J.-K. Sim, C.-R. Lee, Band gap engineering of tandem structured CIGS compound absorption layer fabricated by sputtering and selenization, J. Alloy. Compd., 563 (2013) 207-215.

[46] J. Tauc, R. Grigorovici, A. Vancu, Optical Properties and Electronic Structure of Amorphous Germanium, Phys. Status Solidi B, 15 (1966) 627-637.

[47] D. Lee, K. Yong, Non-vacuum deposition of CIGS absorber films for low-cost thin film solar cells, Korean J. Chem. Eng., 30 (2013) 1347-1358.

[48] C.C. Chen, X. Qi, W. Chang, M. Tsai, I. Chen, C. Lin, P. Wu, K. Chang, The effects of pulse repetition rate on the structural, optical, and electrical properties of CIGS films grown by pulsed laser deposition, Appl. Surf. Sci., 351 (2015) 772-778. 